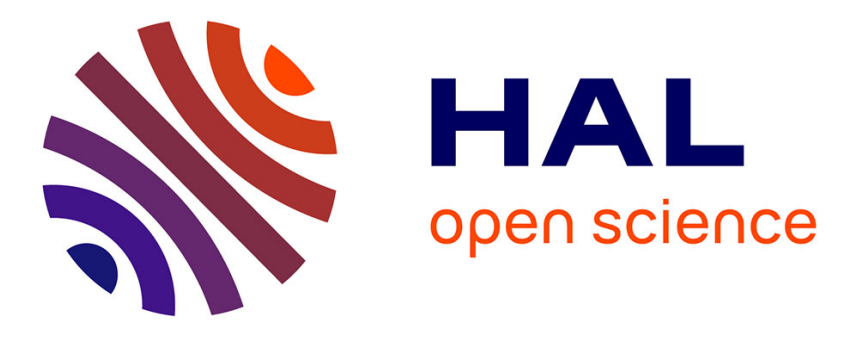

\title{
Supporting Creative Design Processes in Blended Interaction Spaces
}

\author{
Peter Dalsgaard, Kim Halskov, Wendy Mackay, Neil Maiden, Jean-Bernard \\ Martens
}

\section{- To cite this version:}

Peter Dalsgaard, Kim Halskov, Wendy Mackay, Neil Maiden, Jean-Bernard Martens. Supporting Creative Design Processes in Blended Interaction Spaces. Proceedings of the 2015 ACM SIGCHI Conference on Creativity and Cognition (C\&C '15), ACM, Jun 2015, Glasgow, United Kingdom. pp.395-396, 10.1145/2757226.2767184 . hal-01263191

\section{HAL Id: hal-01263191 \\ https://inria.hal.science/hal-01263191}

Submitted on 27 Jan 2016

HAL is a multi-disciplinary open access archive for the deposit and dissemination of scientific research documents, whether they are published or not. The documents may come from teaching and research institutions in France or abroad, or from public or private research centers.
L'archive ouverte pluridisciplinaire HAL, est destinée au dépôt et à la diffusion de documents scientifiques de niveau recherche, publiés ou non, émanant des établissements d'enseignement et de recherche français ou étrangers, des laboratoires publics ou privés. 


\section{Supporting Creative Design Processes in Blended Interaction Spaces}

\author{
Peter Dalsgaard \\ Kim Halskov \\ Aarhus University \\ Aarhus, Denmark \\ dalsgaard@cavi.au.dk \\ halskov@cavi.au.dk
}

\author{
Wendy Mackay \\ Universite Paris-Sud \\ Paris, France \\ Wendy.Mackay@1ri.fr neilmaiden@me.com
}

\author{
Jean-Bernard Martens \\ Technische Universiteit \\ Eindhoven \\ The Netherlands \\ J.B.O.S.Martens@tue.nl
}

\begin{abstract}
Creative processes involve a repertoire of digital devices ranging from mobile phones over tablets and desktop computers to electronic whiteboards and wall-sized displays. While some integration across multiple devices is supported more sophisticated kinds of integration that connect devices and amplify their potential are limited. Many creative practices also rely on physical materials and tools. This will workshop investigate how the combination of physical and digital artifacts can support creative work practices. In this context, we propose to examine: Individual and social creative activities; Creativity methods; Emergence and transformation of design ideas; Generative design materials; Design constraints.
\end{abstract}

\section{Author Keywords}

Design processes; creativity; design materials; design environments; constraints.

\section{ACM Classification Keywords}

H.5.m. Information interfaces and presentation:

Miscellaneous.

\section{INTRODUCTION}

Today, more and more forms of human activity involve a repertoire of digital devices ranging from mobile phones over tablets and desktop computers to electronic whiteboards and wall-sized displays. While some integration across multiple devices is supported by access to shared data, e.g. via cloud computing services, more sophisticated kinds of integration that connect devices and amplify their potential are limited. Interestingly, many creative practices such as design and architecture, to a large extent still rely on physical materials and tools like for instance pen and paper, Post-It notes and whiteboards,

Copyright is held by the owner/author(s).

$C \& C^{\prime} 15$, June 22-25, 2015, Glasgow, United Kingdom

ACM 978-1-4503-3598-0/15/06.

http://dx.doi.org/10.1145/2757226.2767184 which are not connected to nor supported by digital means. Blended Interaction has emerged as a promising approach for conceptualising interaction in physical environments augmented by ICT to blend the power of digital computing and the physical environment. Blended Interaction seeks to combine the virtues of physical and digital artifacts in a complimentary way [6]. This approach is well suited for developing digital support for creative work practices that acknowledge the benefits of current analogue tools and practices, so that the desired properties of each are preserved. This workshop, will investigate how Blended Interaction Spaces (BIS) can support, augment and potentially transform creative work practices.

Specifically we examine the following themes to advance research on IT supported creative practices:

- Individual and social creative activities

- Creativity methods

- Emergence and transformation of design ideas

- Generative design materials

- Creativity constraints

\section{INDIVIDUAL AND SOCIAL CREATIVE ACTIVITIES}

While creativity research has historically focused on the individual lone-genius creator that notion has recently been challenged by researchers arguing for team-based creativity [9]. We pose the thesis that the individual vs. social creation dichotomy is artificial: real-life creativity almost always takes place in both spheres, albeit at different times, leading to the research question: how can Blended Interaction Spaces facilitate seamless integration of individual creative sessions (e.g. using iPads and mobile phones) with collaborative ones (e.g. using wall sized displays in combination with iPads), hereby allowing for ideas to travel across platforms and contextual boundaries?

\section{CREATIVITY METHODS}

A number of interaction design methods support ideation and creativity [1] e.g Future Workshops [7] and Inspiration Card Workshops [4]. However, few traditional creativity methods are supported by digital means. We wish to explore the potential for doing so, as well as discuss the 
pros and cons of using it to support creativity methods, leading us to these questions: how, and to which extent, can creativity methods be supported and/or augmented by Blended Interaction Spaces, and how can new methods harness the potentials of Blended Interaction Spaces?

\section{EMERGENCE AND TRANSFORMATION OF DESIGN IDEAS}

Design ideas often emerge from specific sources of inspiration, and are shaped through negotiation and transformation mediated by design artefacts [5]. While ideation is central to the development of novel interaction concepts that pervade the CHI community, little has been done to examine how ideation and concept development can be supported via IT. Likewise, there are few digital tools that can help researchers explore the emergence and transformation of ideas through a design process and thus provide richer data for understanding the creative process, which in turn could lead to the development of more fruitful methods and tools to support it. This leads to the questions: how can we develop Blended Interaction Spaces to support creativity methods, and how can we track and analyse the emergence of design ideas and the transformation of design ideas across devices in Blended Interaction Spaces?

\section{GENERATIVE DESIGN MATERIALS}

Schön [10] coined the term generative metaphors, generative in the sense that "it generated new perceptions, explanations, and inventions" (ibid 259). Based on experiences from our own work, and supported by insights from the field of creativity studies, we suggest extending the concept to generative design materials, i.e. digital and physical artifacts that, when employed in a design process, support the development and refinement of design concepts. This leads to the questions: how can generative design materials, digital as well as physical, spur ideation and create momentum in a creative process? What are the differences between using digital and physical materials for this end, and how can we combine the two in meaningful ways?

\section{CREATIVITY CONSTRAINTS}

Leading creativity scholars argue that constraints are integral to the creative process; in spite of this, research into constraints has been limited and it will therefore be at the vanguard of future creativity research [11]. Although constraints act as obstructions in a process by determining what cannot be done [8], they also give rise to new opportunities and inspire creative breakthroughs [1] [12], which leads to the questions: what is the nature of creativity constraints and how can they be balanced and managed in a creative process?

\section{ACKNOWLEDGEMENTS}

This research has been support by Innovation Fund Denmark grant 1311-00001B (CIBIS): www.cavi.au.dk/CIBIS.

\section{REFERENCES}

[1] Biskjær, M.B. and Halskov, K.: Decisive constraints as a creative resource in interaction design. Digital Creativity vol 25, 1, 2014, 27-61.

[2] Biskjaer, M., Dalsgaard \& Halskov, K. : Creativity methods in interaction design. In the proceedings of DESIRE 2010.

[3] Fruchter, Renate, et al. (2007). Collaborative design exploration in an interactive workspace. AI EDAM-

Artificial Intelligence Engineering Design Analysis and Manufacturing 21.3, 279-294.

[4] Halskov, K. \& Dalsgaard, P. (2006). Inspiration Card Workshops. Proceedings of DIS 2006, 2006, 2-11.

[5] Halskov, K., Dalsgård, P. The Emergence of Ideas: The interplay between sources of inspiration and emerging design concepts. Journal of CoDesign, 3 (4), 2007, 185211.

[6] Jetter, H. C., Reiterer, H. \& Geyer, F. 2014. Blended Interaction: understanding natural human-computer interaction in post-WIMP interactive spaces. Personal Ubiquitous Comput. 18, 5 (June 2014), 1139-1158.

[7] Jungk, R. \& Müllert, N. Future Workshops: How to create desirable futures. Institute for Social Inventions, London, 1987.

[8] Onarheim, B. (2012). Creativity under Constraints: Creativity as Balancing 'Constrainedness' Doctoral dissertation $(\mathrm{PhD})$. The $\mathrm{PhD}$ School of Economics and Management, Copenhagen Business School.

[9] Sawyer, K. (2012). Explaining creativity. The science of human innovation. 2nd edition. Oxford University Press.

[10] Schön, D. (1979): Generative Metaphor: A perspective on Problem-Setting in Social Policy. In Ortony, A. (ed) (1979): Metaphor and Thought. Cambridge: Cambridge University Press (254-283).

[11] Sternberg, R. J. \& Kaufman, J. C. (2010). Constraints on creativity: Obvious and not so obvious. In J. C. Kaufman \& R. J. Sternberg (Eds.), The Cambridge Handbook of Creativity. (pp. 467-482). Cambridge, UK: Cambridge University Press.

[12] Stokes, P. D. (2006). Creativity from Constraints: The Psychology of Breakthrough. New York: Springer Publishing Company. 